\title{
Influences of experience dimensions on consumer loyalty: the case of travel agencies in East Java
}

\author{
Christina Esti Susanti \\ Business Faculty, \\ Widya Mandala Catholic University, \\ Surabaya, Indonesia \\ Email: susantiesti@yahoo.com \\ *Corresponding author

\section{Purnendu Mandal} \\ College of Business, \\ Lamar University, \\ Texas, USA \\ Email: Purnendu.mandal@lamar.edu
}

\begin{abstract}
In today's competitive environment in the travel industry, businesses must focus on how to create customer loyalty by adopting the overarching theory of experiential marketing. This study investigates the influence of experience dimensions (sense, feel, think, act and relate) on customer loyalty through experiential value in travel agencies in East Java. The customers who purchased travel tickets and hotel vouchers in East Java were studied for data collection. We use random probability sampling as a sample collection technique. Structural equation modelling is used to analyse the collected data. The research shows that sense, feel, think, act and relate factors have positive and significant impact on customer loyalty. This study provides policy directions to marketers who are engaged in tourism agency services and suggests that they pay attention to experience dimensions to garner customer loyalty.
\end{abstract}

Keywords: sense; feel; think; act; relate; experiential value; customer loyalty.

Reference to this paper should be made as follows: Susanti, C.E. and Mandal, P. (2017) 'Influences of experience dimensions on consumer loyalty: the case of travel agencies in East Java', Int. J. Business Excellence, Vol. 13, No. 3, pp.340-354.

Biographical notes: Christina Esti Susanti is a Lecturer and she teaches in post-graduate and doctoral programs at several universities. She received her Doctoral degree in Marketing Management from Airlangga University, Surabaya, Indonesia. Her research interests are in marketing management, consumer behaviour, and services marketing.

Purnendu Mandal is a Professor at the College of Business, Lamar University, Texas, USA. He published over 200 refereed research articles and 20 edited books. He is the Book Series Editor of Managing the Asian Century published by Springer. He serves is editorial board of several international journals. 


\section{Introduction}

The concept of experiential marketing has attracted a lot of attention in marketing practices (Walter et al., 2013). Managers have applied the practices of experiential marketing to great success in a wide variety of industries (Cooney, 2014). Without question, an experiential marketing strategy has potential for improving firm's profits (Jain and Lohia, 2014). The concept of experiential marketing was first introduced in the work of Pine and Gilmore (1997) and then by Schmitt (1999). From Schmitt's (1999) perspective, manufacturer needs to provide unique, positive and memorable experiences to consumers in order to approach, obtain and maintain loyal customers. The basic principle of experiential marketing is to make consumers more involved with products or services, both physically and emotionally. When the products or services are able to deliver a positive and unforgettable experience, consumers will always remember them, even when consuming similar products. If consumers find good experiences of products or services, consciously or unconsciously they will invite others to consume those products or services.

According to Schmitt (1999), there are five types of customer experiences that form the basis of the experiential marketing approach, namely sense, feel, think, act and relate. Sense marketing appeals to the consumer sensory experience gained through sight, sound, touch, taste and smell. Feel marketing appeals to the inner mood and feelings of customers which come from the consumption of products and services performed. The emphasis of think marketing is on intelligence of the consumer experience in producing cognitive experiences. Act marketing allows the consumer experience to develop physical experiences associated with the consumer, and lifestyle as well as the experience gained from social interaction with others. Relate marketing allows consumers to build relationships with social communities and entities through the process of purchasing and consuming products and services.

The attention to experiential marketing in today's business is rising because marketing practitioners come to realise that understanding how consumers experience products and services is crucial for developing customer loyalty toward products and services offered. In this paper we study the influences of sense, feel, think, act and relate to consumer loyalty through experiential value on consumer travel agency in East Java.

The paper is organised in the following way. First, a theoretical framework is presented on experiential marketing. Second, the research methodology and data collection are discussed. Third, the data analysis and results of SEM model are discussed. Finally, the paper presents the conclusions and research limitations.

\section{Theoretical framework}

Schmitt (1999) proposed the concept of strategic experiential marketing including five basic experimental factors such as sense, feel, think, act and relate. Enhancing the experience during the purchasing process can help to maintain customer loyalty. Schmitt suggested that experiential marketing should deliver emotional and functional value. $\mathrm{He}$ further argued that these experiences enhance the value of a product, a brand, or a company. Nevertheless, experiential marketing does not overlook the quality and 
functions of products and services; rather, it enhances customers' emotions and sense stimulation.

Thus, the ability of a company to influence experiential value to certain extent will be determined by the experiential marketing strategy created by the company. Experiential value focuses on the value that customers retain from these experiences. Therefore, to fully understand the various functions of experiential value in service settings, it is necessary to find the relationship between experiential value and other variables, such as loyalty. Customer loyalty encourages consumers to shop, and feel positive about their shopping experience, thus helping attract consumer to familiar brands in the face of a competitive environment.

\subsection{The concepts}

\subsubsection{Experiential marketing}

Schmitt (1999) defined experience as private events that occur in response to some stimulation (provided by marketing efforts before and after purchase). It means that the experience is personal events that occur due to certain stimuli. Schmitt (1999) provide a framework which describes components existing in the experiential marketing. Experiential modules framework involves five types of experience. The first type is sense. Sense is tangible entity and can be perceived as aspects of a product that can be captured by the five human senses, including sight, sound, smell, taste and touch. According to McCole (2004), sensory experience gained by customer from sense of sight, taste, touch and sound.

The second type is feel. Feel can be seen through feelings and emotions. Feel marketing appeals consumer's inner feeling and emotions with the objective of creating affective experiences. The affective experiences can range from positive moods to strong emotions.

The third type is think. Think refers to the intellect with the objective of creating cognitive and problem-solving experiences. A company seeks to challenge the consumer, by providing problem-solving experiences and encourage customers to interact cognitively and/or creatively with company or product.

The fourth type is act. Act refers to behaviours, lifestyles and interactions conducted by consumer as an individual mind and body. The act marketing can enrich the life of customers by targeting their physical experience, showing them alternative ways of doing things, alternative lifestyles and interactions.

The fifth type is relate. Relate contains aspects of sense, feel and think. Relate individually connect customers with the community or culture. Relate is formed through self-improvement, socio-economic status and image.

\subsubsection{Experiential value}

Shamim and Ghazali (2014) states that experiential value can be created through consumption experience. While Za'ba and Kumar (2015) asserted that the experiential value will be determined when consumer evaluates values. The values include aesthetics/beauty (aesthetics), excitement/interest (playfulness), excellent service (service excellence) and return on investment made by the consumer (customer return on investment - CROI). 


\subsubsection{Customer loyalty}

Concept of customer loyalty has attracted attention from many academics and practitioners. Taylor et al. (2013) defined customer loyalty as a commitment to buy a preferred product or service in the future. A consumer will devote to re-purchase on an ongoing basis. Kotler and Keller (2007) measure customer loyalty with indicators such as repeat purchase (loyalty towards the purchase of products), retention (resistance to negative impact on the company) and referrals.

\subsection{Influences between variables}

Customer experiential value is a very dynamic construct. It changes due to advancements in adopting various experiential marketing strategies in the service industry, even though there are indications that some influential factors of experiential value affect customer loyalty. The experiential value focuses on creating fresh connections between brands and consumers out in the world where things happen. Connection in the form of experience that is personally relevant, memorable, interactive and emotional leads to increased loyalty. It seems there is a positive relationship between experiential marketing, experiential value and customer loyalty, particularly if customers have a nice experience with the product or service. In this situation they are more likely to use the same product or service when they need it again (Ongori et al., 2013).

Previous study conducted by Maghnati et al. (2012) provides strong evidence that sense, feel, think, act and relate has positive influences on the creation of experiential value. The research confirmed the significant positive relationships of sense experiences, feel experience, act experience, relate experience and think experience with experiential value. Moreover, Chao (2015) shows that under the impact of two mediating variables (namely, brand image and satisfaction) experimental marketing and loyalty do not passively affect each other and one must use brand image and satisfaction as the mediator. The results indicated that during the running of fitness clubs, the subjective perception of the customers on brand image and customer satisfaction is of great importance. In addition, results from this study also indicate that experimental marketing has a positive effect on brand image.

\subsection{Research hypothesis}

Indonesia, particularly East Java area, is experiencing increasing tourist attraction. The travel industry as such in East Java is very competitive. It seems however the travel agencies are not using their full potential in promoting tourism and not implementing any particular marketing strategy. Experiential marketing by travel agencies in East Java could be an effective strategy in creating customer loyalty. Experiential routes to persuasion has been studied in developing countries context (Zarantonello et al., 2013), but there has been no study for East Java. This work is motivated by the potential opportunity in contributing to experiential marketing in a particular developing country setting.

This study takes cue from the work conducted by Maghnati et al. (2012) but applies in the context of a developing country. Maghnati et al. (2012) suggest that the experience dimensions (sense, feel, think, act and relate) have positive influences on the creation of 
experiential value. We want to examine if such influences are prevalent in travel agencies in East Java. Through data collection and analysis, the following hypotheses are tested:

Hypothesis 1 Sense has a positive and significant influence on experiential value in the consumer travel agency in East Java.

Hypothesis 2 Feel has a positive and significant influence on experiential value in the consumer travel agency in East Java.

Hypothesis 3 Think has a positive and significant influence on experiential value in the consumer travel agency in East Java.

Hypothesis 4 Act has a positive and significant influence on experiential value in the consumer travel agency in East Java.

Hypothesis 5 Relate has a positive and significant influence on experiential value in the consumer travel agency in East Java.

Hypothesis 6 Experiential value has a positive and significant influence on customer loyalty in the consumer travel agency in East Java.

Figure 1 shows how the experience dimensions (sense, feel, think, act and relate) could be linked to experiential value. Also, how the experiential value affects customer loyalty in consumer travel agency is shown in this diagram. This is the general form of the research model which we will be testing for travel industry in Surabaya.

Figure 1 Research model

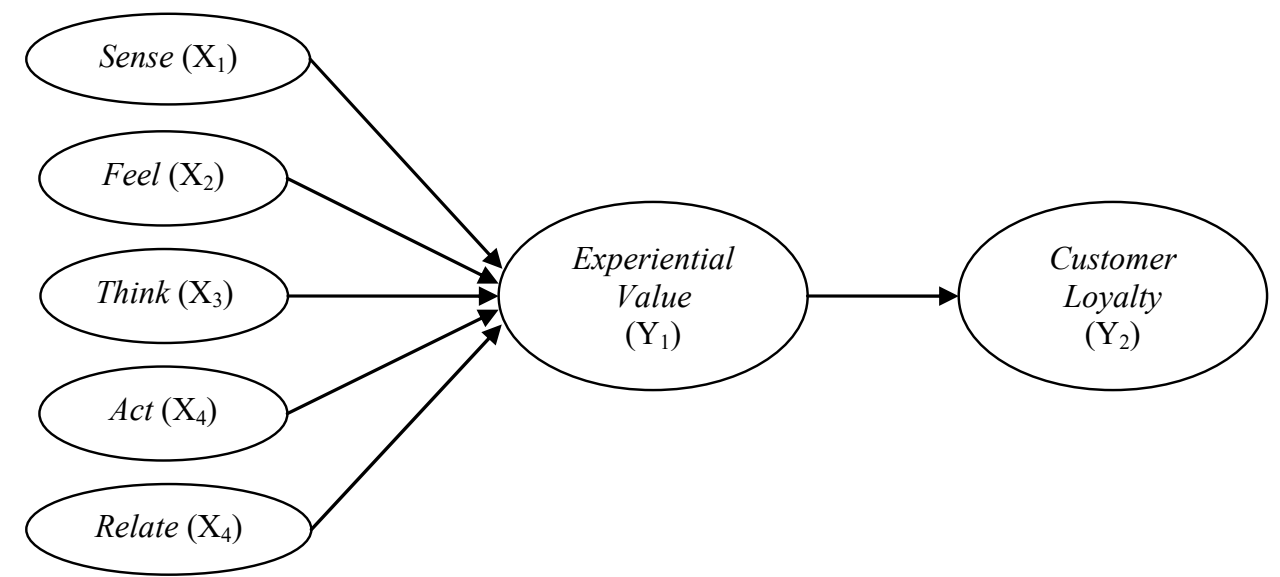

We employed quantitative research methodology, namely questionnaire survey, to generate the primary data set and examine the nature of relationships. Quantitative research can be interpreted as research that is based on the philosophy of positivism, is used to examine the population or a particular sample; the sampling technique is generally done at random, using a data collection instrument, data analysis and statistical nature. 


\section{Research method}

Population in this research is the consumers of travel agencies in East Java who buy travel tickets and hotel vouchers. It is decided to collect data from 200 participants. The sample size of 200 is considered adequate; based on the opinion of Hair et al. (2006, p.605) a sample of 100-200 people is enough to represent a causal study. The sampling technique used in this study is non-probability sampling. Non-probability sampling is a sampling technique that does not give an opportunity or equal opportunity for each element or member of the population to be selected into the sample.

Sample of the study has critical characteristics, e.g., respondent has bought travel tickets and hotel vouchers in travel agency in East Java, minimum age 17 years and lived in East Java. The sampling technique used in this research is accidental sampling. The study follows the steps:

1 questionnaire given to respondents

2 respondents fill in the questionnaire according to his own judgement and the questionnaire answers are processed immediately.

Data analysis tool used is structural equation modelling (SEM).

\subsection{Descriptive statistics}

Based on the survey results, it is revealed that sense, feel, think, act, relate, experiential value and customer loyalty has the means 3.0 or higher. This indicates that respondents agree with the statements that are used to collect the data in this study.

Table 1 Statistic descriptive of sense

\begin{tabular}{|c|c|c|c|c|c|c|c|c|}
\hline \multirow{2}{*}{ No. } & \multirow{2}{*}{ Item } & \multicolumn{5}{|c|}{ Respondents } & \multirow{2}{*}{ Means } & \multirow{2}{*}{$\begin{array}{c}\text { Std. } \\
\text { deviation }\end{array}$} \\
\hline & & $S A$ & $A$ & $N$ & $D$ & $S D$ & & \\
\hline 1 & $\begin{array}{l}\text { Design of the travel agency outlet } \\
\text { is nice. }\end{array}$ & 14 & 48 & 38 & 62 & 38 & 3.310 & 1.228 \\
\hline 2 & $\begin{array}{l}\text { The travel agency outlet makes me } \\
\text { comfortable. }\end{array}$ & 22 & 40 & 38 & 58 & 42 & 3.290 & 1.305 \\
\hline 3 & $\begin{array}{l}\text { Interior design of the travel agency } \\
\text { outlet is very attractive. }\end{array}$ & 18 & 44 & 36 & 58 & 44 & 3.330 & 1.288 \\
\hline Total & & & & & & & 3.310 & 1.274 \\
\hline
\end{tabular}

Note: Description: strongly agree $-\mathrm{SA}$, agree $-\mathrm{A}$, neutral $-\mathrm{N}$, disagree $-\mathrm{D}$, strongly disagree $-\mathrm{SD}$.

Sense in this study was measured by outlet is nice, outlet makes comfortable and outlet is very attractive. According to Table 1 it appears that the average value of the highest sense items is interior design of the travel agency outlet is very attractive (3.330) with standard deviation is 1.288. The results showed that the respondents agree if the travel agency had a room laid out attractively. For example, the wall mounted many pictures of tourist destinations, installed a lot of travel packages are offered and mounted image some travel tour group ever handled. 
Feel in this study was measured by services provided by the travel agency makes happy, services provided the travel agency makes avoid pressure of communication, and feel happy dealing with the staffs of the travel agency. According to Table 2, it appears that the average value of the highest feel items is that I feel happy dealing with the staffs of travel agencies (3.560) with standard deviation is 1.113 . These results prove that the respondents feel comfortable when dealing with the company's staff when completing a transaction. This is possible because the company's staffs are friendly in serving customers and good understanding of all kinds of services offered by the company.

Table 2 Statistic descriptive of feel

\begin{tabular}{|c|c|c|c|c|c|c|c|c|}
\hline \multirow{2}{*}{ No. } & \multirow{2}{*}{ Item } & \multicolumn{5}{|c|}{ Respondents } & \multirow{2}{*}{ Means } & \multirow{2}{*}{$\begin{array}{c}\text { Std. } \\
\text { deviation }\end{array}$} \\
\hline & & $S A$ & $A$ & $N$ & $D$ & $S D$ & & \\
\hline 1 & $\begin{array}{l}\text { Services provided by the travel } \\
\text { agency make me happy. }\end{array}$ & 8 & 32 & 50 & 82 & 28 & 3.450 & 1.048 \\
\hline 2 & $\begin{array}{l}\text { Services provided the travel agency } \\
\text { make me avoid pressure of } \\
\text { communication. }\end{array}$ & 16 & 26 & 42 & 72 & 44 & 3.510 & 1.202 \\
\hline 3 & $\begin{array}{l}\text { I feel happy dealing with the staffs } \\
\text { of the travel agency. }\end{array}$ & 12 & 24 & 42 & 84 & 38 & 3.560 & 1.113 \\
\hline \multicolumn{2}{|c|}{ Total } & & & & & & 3.506 & 1.121 \\
\hline \multicolumn{2}{|r|}{ Statistic descriptive of think } & & & & & & & \\
\hline \multirow{2}{*}{ No. } & \multirow{2}{*}{ Item } & \multicolumn{5}{|c|}{ Respondents } & \multirow{2}{*}{ Means } & \multirow{2}{*}{$\begin{array}{c}\text { Std. } \\
\text { deviation }\end{array}$} \\
\hline & & $S A$ & $A$ & $N$ & $D$ & $S D$ & & \\
\hline 1 & $\begin{array}{l}\text { Participating in promotion of the } \\
\text { travel agency makes me able to } \\
\text { share the experience of those who } \\
\text { have in common. }\end{array}$ & 12 & 30 & 40 & 104 & 14 & 3.390 & 1.024 \\
\hline 2 & $\begin{array}{l}\text { I feel it obliged to tell the products } \\
\text { or services of travel agency. }\end{array}$ & 16 & 48 & 40 & 52 & 44 & 3.300 & 1.275 \\
\hline \multicolumn{2}{|c|}{ Total } & & & & & & 3.345 & 1.150 \\
\hline
\end{tabular}

Think in this study was measured by participating in promotion of the travel agency makes able to share the experience of those who have in common and I feel it obliged to tell the products or services of travel agency. According to Table 3, it appears that the average value of the highest think items is that participating in the promotion of the travel agency makes me able to share the experience of those who have in common (3.390) with standard deviation is 1.024 . It is proved that by engaging in promotional activities organised by company respondents felt the benefits that can share experiences with other customers and can exchange experiences with other customers in connection with his experience enjoy services of the travel agency. 
Table 4 Statistic descriptive of act

\begin{tabular}{|c|c|c|c|c|c|c|c|c|}
\hline \multirow{2}{*}{ No. } & \multirow{2}{*}{ Item } & \multicolumn{5}{|c|}{ Respondents } & \multirow{2}{*}{ Means } & \multirow{2}{*}{$\begin{array}{c}\text { Std. } \\
\text { deviation }\end{array}$} \\
\hline & & $S A$ & $A$ & $N$ & $D$ & $S D$ & & \\
\hline 1 & $\begin{array}{l}\text { The products or services of travel } \\
\text { agency affect my lifestyle. }\end{array}$ & 12 & 38 & 44 & 70 & 36 & 3.400 & 1.163 \\
\hline 2 & $\begin{array}{l}\text { I want to explore the travel agency } \\
\text { to improve lifestyle. }\end{array}$ & 8 & 56 & 26 & 64 & 46 & 3.420 & 1.232 \\
\hline 3 & $\begin{array}{l}\text { The products or services of a travel } \\
\text { agency make me want to change } \\
\text { lifestyle. }\end{array}$ & 0 & 46 & 56 & 62 & 36 & 3.440 & 1.038 \\
\hline Total & & & & & & & 3.420 & 1.144 \\
\hline
\end{tabular}

Act in this study was measured by the products or services of travel agency affect lifestyle, want to explore the travel agency to improve lifestyle, and the products or services of a travel agency make me want to change lifestyle. According to Table 4, it appears that the average value of the highest act items is that the products or services of a travel agency make me want to change lifestyle (3.440) with standard deviation is 1.038 . The results showed that the respondents' experience with a travel agency to make the respondents want to change their lifestyle. This means that the respondents' experience with the travel agency brought a tremendous impact so great an impact on customers' willingness to change lifestyle.

Table 5 Statistic descriptive of relate

\begin{tabular}{|c|c|c|c|c|c|c|c|c|}
\hline \multirow{2}{*}{ No. } & \multirow{2}{*}{ Item } & \multicolumn{5}{|c|}{ Respondents } & \multirow{2}{*}{ Means } & \multirow{2}{*}{$\begin{array}{c}\text { Std. } \\
\text { deviation }\end{array}$} \\
\hline & & $S A$ & $A$ & $N$ & $D$ & $S D$ & & \\
\hline 1 & $\begin{array}{l}\text { Travel agency does not only sell } \\
\text { services but also entertain } \\
\text { customers. }\end{array}$ & 0 & 40 & 62 & 72 & 26 & 3.420 & 0.955 \\
\hline 2 & $\begin{array}{l}\text { I am delighted to be given the } \\
\text { services of travel agency. }\end{array}$ & 0 & 52 & 48 & 64 & 36 & 3.420 & 1.065 \\
\hline Total & & & & & & & 3.420 & 1.010 \\
\hline
\end{tabular}

Relate in this study was measured by travel agency does not only sell services but also entertain customers and delighted to be given the services of travel agency. According to Table 5, it appears that average respondents agree that the travel agency does not only sell services but also entertain customers and customers are delighted to be given the services of travel agency. And remarkably, the average of the two items are high (3.420) with standard deviation is 0.955 for the travel agency does not only sell services and 1.065 for customers are delighted to be given the services of travel agency. The results showed that in the opinion of customers travel agents not only sell services, but also entertain customers. In addition, customers also had the pleasure to enjoy the services provided by a travel agent. 
Table 6 Statistic descriptive of experiential value

\begin{tabular}{|c|c|c|c|c|c|c|c|c|}
\hline \multirow{2}{*}{ No. } & \multirow{2}{*}{ Item } & \multicolumn{5}{|c|}{ Respondents } & \multirow{2}{*}{ Means } & \multirow{2}{*}{$\begin{array}{c}\text { Std. } \\
\text { deviatior }\end{array}$} \\
\hline & & $S A$ & $A$ & $N$ & $D$ & $S D$ & & \\
\hline 1 & $\begin{array}{l}\text { Joining forum of travel agency is } \\
\text { beneficial. }\end{array}$ & 0 & 52 & 48 & 64 & 36 & 3.420 & 1.065 \\
\hline 2 & $\begin{array}{l}\text { The price set by the travel agency } \\
\text { is balanced between products and } \\
\text { services offered. }\end{array}$ & 10 & 44 & 60 & 54 & 32 & 3.270 & 1.127 \\
\hline 3 & $\begin{array}{l}\text { Recommending others about the } \\
\text { products or services of travel } \\
\text { agency makes me satisfied. }\end{array}$ & 12 & 42 & 60 & 66 & 20 & 3.200 & 1.073 \\
\hline 4 & $\begin{array}{l}\text { I am satisfied with the products } \\
\text { and services offered by travel } \\
\text { agency. }\end{array}$ & 8 & 44 & 72 & 30 & 46 & 3.310 & 1.169 \\
\hline Total & & & & & & & 3.300 & 1.109 \\
\hline
\end{tabular}

Experiential value in this study was measured by joining forum of travel agency is beneficial, the price set by the travel agency is balanced between products and services offered, recommending others about the products or services of travel agency makes satisfied, and satisfied with the products and services offered by travel agency. According to Table 6, it appears that average respondents agree that joining forums of travel agency is beneficial, the price set by the travel agency is balanced between products and services offered, recommending others about the products or services of travel agency makes me satisfied, and I am satisfied with the products and services offered by travel agency. The average value of the highest experiential value items is that joining forum of travel agency is beneficial (3.420) with standard deviation is 1.065 . These results indicate that customers feel lucky for them when joined with the travel agency. In other words, customers feel lucky when using a travel agent to satisfy their needs and desires in terms of travelling.

Table 7 Statistic descriptive of customer loyalty

\begin{tabular}{|c|c|c|c|c|c|c|c|c|}
\hline \multirow{2}{*}{ No. } & \multirow{2}{*}{ Item } & \multicolumn{5}{|c|}{ Respondents } & \multirow{2}{*}{ Means } & \multirow{2}{*}{$\begin{array}{c}\text { Std. } \\
\text { deviation }\end{array}$} \\
\hline & & $S A$ & $A$ & $N$ & $D$ & $S D$ & & \\
\hline 1 & $\begin{array}{l}\text { I would recommend the travel } \\
\text { agency to friends, neighbours, } \\
\text { relatives and co-workers. }\end{array}$ & 18 & 46 & 58 & 48 & 30 & 3.130 & 1.195 \\
\hline 2 & $\begin{array}{l}\text { I am a loyal customer of travel } \\
\text { agency. }\end{array}$ & 12 & 48 & 56 & 66 & 18 & 3.150 & 1.077 \\
\hline 3 & $\begin{array}{l}\text { In the future I am willing to pay } \\
\text { more for products or services of } \\
\text { travel agency. }\end{array}$ & 14 & 40 & 62 & 36 & 48 & 3.320 & 1.238 \\
\hline 4 & $\begin{array}{l}\text { I will prioritise travel agency when } \\
\text { I wanted to buy tourism services. }\end{array}$ & 12 & 42 & 50 & 50 & 46 & 3.380 & 1.221 \\
\hline 5 & $\begin{array}{l}\text { I will not switch to another travel } \\
\text { agency even though I have } \\
\text { experienced disappointment. }\end{array}$ & 10 & 40 & 54 & 78 & 18 & 3.270 & 1.043 \\
\hline Total & & & & & & & 3.250 & 1.155 \\
\hline
\end{tabular}


Experiential value in this study was measured by would recommend the travel agency to friends, neighbours, relatives and co-workers; be a loyal customer of travel agency; willing to pay more for products or services of travel agency; will prioritise travel agency when they wanted to buy tourism products; and will not move to another travel agency when I experience problems with the product or services.

According to Table 7, it appears that the average value of the highest customer loyalty items is 'I will prioritise travel agency when they wanted to buy tourism services' (3.380) and the lowest is 'I would recommend the travel agency to friends, neighbours, relatives and co-workers' (3.130). The results showed that to meet the needs and desires of travel services, respondents continue to use the services offered by the travel agency as a priority. In other words, for the future, to meet the needs and desires of travel services, the travel agency will be chosen again by the customer.

\subsection{Test assumptions SEM}

Univariate normality test results that the p-value, chi-squared skewness and kurtosis are greater than 0.05 , which indicates that the data are normally distributed. Validity test is intended to determine whether the questions in the questionnaire sufficiently representative. A variable have a good validity as latent construct or other variables if the absolute value of the t-load factor (factor loadings) is greater than the critical value (1.96). Results show evidences that all indicators of t-statistic have a value more than 1.96. Reliability test is used to measure a questionnaire which is an indicator of the variables. The method used to calculate the reliability of instrument is construct reliability index. Based on data analysis, value of variables reliability is a minimum 0.60. Thus, variables are declared as reliable significantly and can be used for further analysis.

\subsection{Goodness of fit index}

There are various types of fit index used to measure the degree of correspondence between the models hypothesised by the data presented. Researchers are expected to conduct tests using some fit index to measure the 'truth' model it proposes. Some indexes suitability and cut-off value that is used to test whether a model can be accepted or rejected as in Table 8 . Based on these results, it proved that the research model proposed in this study met the criteria of fit.

Table 8 Goodness of fit index

\begin{tabular}{lccc}
\hline Goodness of fit index & Cut-off value & Result & Description \\
\hline RFI & $\geq 0.9$ & 0.97 & Good fit \\
RMSEA & $<0.08$ & 0.03 & Good fit \\
NFI & $\geq 0.9$ & 0.92 & Good fit \\
IFI & $\geq 0.9$ & 0.96 & Good fit \\
CFI & $\geq 0.9$ & 0.94 & Good fit \\
NNFI & $\geq 0.9$ & 0.98 & Good fit \\
\hline
\end{tabular}

Source: Data processed 


\section{Hypothesis testing}

Hypothesis test results are summarised in Table 9.

Table 9 Hypothesis testing

\begin{tabular}{lcccc}
\hline No & Influence among variables & Loading factor & T values & Description \\
\hline 1 & Sense $\rightarrow$ Experiential value & 0.26 & 2.29 & Significant \\
2 & Feel $\rightarrow$ Experiential value & 0.17 & 2.30 & Significant \\
3 & Think $\rightarrow$ Experiential value & 0.28 & 2.65 & Significant \\
4 & Act $\rightarrow$ Experiential value & 0.24 & 4.39 & Significant \\
5 & Relate $\rightarrow$ Experiential value & 0.43 & 3.64 & Significant \\
6 & Experiential value $\rightarrow$ Customer loyalty & 0.37 & 4.54 & Significant \\
\hline & Source: $\quad$ Data processed
\end{tabular}

Based on Table 9, it can be seen that the influences between variables tested in this study are positive and significant. Calculated values of sense (LF 0.26, T values 2.29), feel (LF 0.17, T values 2.30), think (LF 0.28, T values 2.65), act (LF 0.24, T values 4.39) and relate (LF 0.43, $\mathrm{T}$ values 3.64 ) have a significant effect on experiential value travel agency in East Java. Thus it can be said that with the change of experiential marketing itself there will be a change in experiential value in travel agencies in East Java. Their experiential value associated with repeated use of the product indicates that there has been a relationship between the customer and the company in the process of product consumption. Creating experiential value can be done by providing an unforgettable experience in a product. So, in addition to the features and benefits, the experience is also an important aspect that needs to be considered by the company to gain experiential value. Experience in marketing can be created by stimulating sense, feel, think, act and relate.

With regard to effect of experiential value to customer loyalty (LF 0.37, T values 4.54), it can be concluded that experiential value has significant influence on customer loyalty in travel agent in East Java.

\section{Discussions}

The influence of sense to experiential value is positive and significant, means that the higher the level of customer experience to outlet is nice, outlet makes comfortable and the outlet is very attractive to the travel agency in East Java, the experiential value perceived by the customer on a travel agency in East Java will increase significantly. Based on these results the first hypothesis of this study is accepted. The result is consistent with the theory put forward by Holbrook (1999) suggesting that a delightful consumer experience can provide functional and emotional value to the customer. Holbrook (1999) argues for the recognition of important experiential aspects of consumption. Consumption experience is a phenomenon directed toward the pursuit of fantasies, feelings and fun.

The result supports the research done by Maghnati et al. (2012) which suggests that variable sense has a positive influence on experiential value. This study helps industry to gain further understanding the impacts of sense experience, feel experience, think 
experience, act experience and relate experience on the experiential value. By understanding the antecedents of experiential value, the research allows the industry players to use experiential marketing effectively in producing the best products and services ever rendered to customers. The research study provides insights for the industry to have an in-depth understanding towards the factors (i.e., sense experience, feel experience, think experience, act experience and relate experience) that contributing to the experiential value with their customers. Therefore, this understanding enables the producers in identifying relevant approaches to build strong experiential value with their valued customers.

Influence of feel on experiential value is positive and significant. Influence feel on experiential value is positive and significant, means that the higher the level of experience of the customer associated with services provided by the travel agency makes happy, services provided the travel agency makes avoid pressure of communication, and feel happy dealing with the staffs of the travel agency of travel agency travel agent in east Java, the experiential level of customer perceived value to travel agency in east Java will increase significantly. Based on this result, the third hypothesis of the research is accepted. The result reinforces the theory of Gentile et al. (2007) which states that experiential value can be created through consumption experience. Gentile et al. (2007) suggest "customer experience is strictly personal and implies the customer involvement at different levels (rational, emotional, sensorial, physical and spiritual)".

Influence of think on experiential value is positive and significant. Influence think on experiential value is positive and significant, means that the higher the level of experience of the customer associated with participating in the promotion of the travel agency makes able to share the experience of those who have in common and feel it is obliged to tell the products or services of travel agency travel agent in East Java, the experiential level of customer perceived value to travel agency in east Java will increase significantly. Based on this result, the third hypothesis of the research is accepted. The result is consistent with the theory suggested by Schmitt (1999) about a good way to create a campaign to lure customers think. Research conducted by Schmitt (1999) has demonstrated the importance of experience in various settings (e.g., stores, events and in online and social media environments).

Effect of act on experiential value is positive and significant. Influence act on experiential value is positive and significant, means that the higher the level of customer experience associated with the products or services of travel agency affect lifestyle, want to explore the travel agency to improve lifestyle, and the products or services of a travel agency make me want to change lifestyle in a travel agency in East Java, the rate of the value perceived by the customer on a travel agency in East Java will increase significantly. Based on these results, the fourth hypothesis of the research is accepted. The result reinforces the theory of Schmitt (1999) which states that the act is intended to influence behaviour, lifestyle and interaction with consumers. Act is one way to establish customer perception of products and services are concerned. The result strengthens the research conducted by Maghnati et al. (2012) which revealed that the variable act have an effect to consumer in creating experiential value.

Influence relate to experiential value is positive and significant, means that the higher the level of customer experience related to the travel agency does not only sell services but also entertain customers and delighted to be given the services of a travel agency in the travel agency in East Java, the level of experiential value perceived by the customer 
on a travel agency in East Java will increase significantly. Based on this result, the fifth hypothesis of the research is accepted. The result explains the theory of how experiential value, as a customer's perception of product or service, can be achieved through the use of direct or indirect observation [Mathwick et al. (2001) in Ongori et al. (2013)]. Holbrook (1999) argues that the consumption experience as good interaction, feelings, and the pleasant atmosphere will impact on consumer decision-making process. The results support and reinforce the results of research conducted by Maghnati et al. (2012) which states that the variable relate has a positive influence on experiential value.

Effect of experiential value to customer loyalty is positive and significant. Effect of experiential value to customer loyalty is positive and significant, means that the higher the level of experiential value perceived by the customer to travel agency in East Java, the level of customer satisfaction will be increased significantly. Based on this result, the sixth hypothesis of the research is accepted. The results support the theory suggested by Mattila and Wirtz (2001) which states that a strong and positive emotions in the values of experience when consuming product will enhance the relationship between customer and company. Research conducted by Mattila and Wirtz (2001) showed that when the arousal levels of ambient scent and background music matched, consumers' evaluations of the shopping experience were enhanced. Their research provides empirical support for the intuitive belief that when the stimuli in the environment act together to provide a coherent atmosphere, the individual in the environment will react more positively.

Results of this study support research conducted by Maghnati et al. (2012). Experiential value has a positive and significant impact on customer satisfaction that also indicates relationship between experiential value and customer loyalty. The result shows that the influence of experiential value on customer loyalty is positive and significant. It proves that in order to gain consumer loyalty, marketers in travel agency industry should pay attention to experiential value. Experiment results in this study are helpful in understanding the industry in terms of consumer perspectives across experimental marketing, experiential value and customer loyalty. This study has two main conclusions. First of all, the industry should focus on customer experience. In order to create customer loyalty, it must use experiential value. Secondly, results from the study show that experimental marketing is a very important method in establishing experiential value for consumers, which in turn promotes an increase in customer loyalty.

\section{Conclusions and recommendations}

Customer experiences of products and services provided by travel agencies arise in variety settings when customers search for, shop for, and consume the products and services. Based on the results of hypothesis testing and discussion, we conclude that all hypotheses proposed in this study have positive and significant influences. The results demonstrate that experience variables can be broken down into five dimension (sense, feel, think, act and relate) which could be differentially evoked for various products and services. This research uses five dimensions as exogenous variables to explain endogenous variables (customer loyalty) through an intervening variable (experiential value). The results of this study can be used as a reference for those who want to undertake similar research or carry out further research, particularly regarding the concept or theory that supports the marketing management associated with experiential marketing on customer loyalty through customer value. Further research should explore 
other models and research methods relating experiential marketing and customer loyalty in tourism industry.

This study demonstrated the effect of sense, think, feel, act and relate to customer loyalty through experiential value in travel agencies in East Java. The study indicates that the experiential value strongly influence consumer experience when the company does just not only sell products or services to customers but also provide entertainment to customers. It is necessary for business managers to increase customer satisfaction. Given the importance of customer loyalty, the managers must pay attention to the elements of experiential value. It means that, during the time of service, marketers must provide customer an experience which has a true value.

\section{Acknowledgements}

Authors are grateful to reviewers for their suggestions which contributed to significant improvement in the quality of the final submission.

\section{References}

Chao, R-F. (2015) 'The impact of experimental marketing on customer loyalty for fitness clubs: using brand image and satisfaction as the mediating variables', The Journal of International Management Studies, Vol. 10, No. 2, pp.52-60.

Cooney, T.M. (2014) 'Entrepreneurship skills for growth-orientated businesses', Report for the Workshop on Skills Development for SMEs and Entrepreneurship, pp.1-23.

Gentile, C., Spiller, N. and Noci, G. (2007) 'How to sustain the customer experience: an overview of experience components that co-create value with the customer', European Management Journal, Vol. 25, No. 5, pp.395-410.

Hair, J.F., Black, W.C., Babin, B.J., Anderson, R.E. and Tatham, R.L. (2006) Multivariate Data Analysis (Vol. 6), Pearson Prentice Hall, Upper Saddle River, NJ.

Holbrook, M.B. (1999) 'Introduction to consumer value', in Holbrook, M.B. (Ed.): Consumer Value: A Framework for Analysis and Research, pp.1-28, Routledge, New York.

Jain, S. and Lohia, S. (2014) 'Experiential marketing: emerging issues and suggestions', International Journal of Advances in Management and Economics, Vol. 3, No. 2, pp.197-203.

Kotler, P. and Keller, K.L. (2007) Marketing Management, Pearson, New York.

Maghnati, F., Ling, K.C. and Nasermoadeli, A. (2012) 'Exploring the relationship between experiential marketing and experiential value in the smartphone industry', International Business Research, Vol. 5, No. 11, pp.169-177.

Mattila, A.S. and Wirtz, J. (2001) 'Congruency of scent and music as a driver of in-store evaluations and behavior', Journal of Retailing, Vol. 77, No. 2, pp.273-289.

McCole, P. (2004) 'Dealing with complaints in services', International Journal of Contemporary Hospitality Management, Vol. 16, No. 6, pp.345-354.

Ongori, J.K., Iravo, M. and Munene, C.E. (2013) 'Factors affecting performance of hotels and restaurants in Kenya: a case of Kisii County', Interdisciplinary Journal of Contemporary Research in Business, Vol. 4, No. 12, pp.897-928.

Pine, J.B. and Gilmore, J.H. (1997) The Experience Economy, Harvard Business School Press, Boston, MA.

Schmitt, B. (1999) Experiential Marketing: How to Get Customers to Sense, Feel, Think, Act, Relate to Your Company and Brands, The Free Press, New York. 
Shamim, A. and Ghazali, Z. (2014) 'A conceptual model for developing customer value co-creation behaviour in retailing', Global Business and Management Research: An International Journal, Vol. 6, No. 3, pp.185-196.

Taylor, B.B., Taylor, M.H., Dinter, T. and Bracher, A. (2013) 'Estimation of relative phycoerythrin concentrations from hyperspectral underwater radiance measurements - a statistical approach', Journal of Geophysical Research: Oceans, Vol. 118, No. 6, pp.1-13.

Walter, N, Cleff, T. and Chu, G. (2013) 'Brand experience's influence on customer satisfaction and loyalty: a mirage in marketing research?', International Journal of Management Research and Business Strategy, Vol. 2, No. 1, pp.1-17.

Za'ba, A.N. and Kumar, D.M. (2015) 'Factors that influence experiential value of timeshare owners toward timeshare purchasing in Malaysia', Information Management and Business Review, Vol. 7, No. 1, pp.23-28.

Zarantonello, L., Jedidi, K. and Schmitt, B.H. (2013) 'Functional and experiential routes to persuasion: an analysis of advertising in emerging versus developed markets', Journal of Research in Marketing, Vol. 30, No. 1, pp.46-56. 